\title{
Enzymatic activity and organic substrates on a sandy beach of the Ligurian Sea (NW Mediterranean) influenced by anthropogenic pressure
}

\author{
Cristina Misic* ${ }^{*}$ Anabella Covazzi Harriague
}

Dipartimento per lo Studio del Territorio e delle sue Risorse, Università di Genova, C.so Europa 26, 16132 Genova, Italy

\begin{abstract}
Enzymatic activities (leucine aminopeptidase, LA; $\beta$-glucosidase, BG; alkaline phosphatase, AP), their related substrates and the bacterial abundance and biomass were studied over $1 \mathrm{yr}$ in 2 adjacent areas of a sandy beach: one occupied by the structures of a private swimming establishment and undergoing major reconstruction work (impacted area), and the other in a more natural area (reference area). Both areas were oligotrophic, characterised by low organic matter content (with a notable contribution from the autotrophic biomass) and low enzymatic activity values. Bacterial abundance did not show significant changes, either spatially or temporally, suggesting that they quickly overcame anthropogenic forcing and seasonal fluctuations under the environmental and trophic conditions. The absence of positive correlations between carbohydrates and enzymatic activities suggested the adverse influence of refractory organic matter. Nevertheless, when the environmental conditions were favourable and bacteria were supported by larger $\mathrm{N}$ inputs from the sea, the carbohydrate became a trophic resource, thus suddenly changing the enzyme ratios. A multivariate analysis highlighted the predominance of the seasonal over the anthropogenic influence, suggesting a rapid recovery in the impacted area. Nevertheless, changes were observed for the functional relationships between the parameters, in particular those related to the trophic quality of the organic material (lower in the impacted area) and the enzymatic hydrolysis. The coupling of LA and AP was generally tight in order to overcome the P deficiency and, in the impacted area, to overcome trophic limitations related to the input of inorganic debris and refractory organic materials.
\end{abstract}

KEY WORDS: Aminopeptidase · $\beta$-glucosidase · Phosphatase · Bacteria · Organic matter degradation · Beach environment

Resale or republication not permitted without written consent of the publisher

\section{INTRODUCTION}

Extracellular enzymatic activity is the initial response of a microbial community to environmental changes (Karner \& Rassoulzadegan 1995) and has often been described as the limiting step for the degradation and recycling of organic matter by bacteria in particular (Andersen-Elvehoy \& Thingstad 1991, Christian \& Karl 1995). The fast synthesis of enzymes by cells and the generally well-known induction-suppression relationships between enzymes and organic substrates (Boetius \& Lochte 1994, Taylor et al. 2003) would suggest that enzyme determination could be an effective tool for inferring available organic matter sources in natural systems (Boschker \& Cappenberg 1998) and, when linked to other biological parameters, for the development of a classification technique for monitoring the trophic (Sala et al. 2001, Taylor et al. 2003) and ecological (Alvarez \& Guerrero 2000, Nakamura \& Takaya 2003) conditions of different environments.

Although the enzymatic activity of sea sediments has been extensively studied at a number of sites, little information is available on littoral environments, in particular on beaches (Podgórska \& Mudryk 2003, Mudryk 2004, Misic \& Fabiano 2005). Beaches, owing 
to their nature as the boundary between the sea and the land, may be considered as preferential degradation sites for organic matter of very different origins (Brown \& McLachlan 1990, Misic \& Fabiano 2005), and several external pressures may affect the biological processes of beaches and nearshore environments (Defeo \& McLachlan 2005). The coarse sediments characteristic of these highly hydrodynamic environments allow notable pore-water and particle flows in the deep layers of the sediments, resulting in living conditions that are shaped by biogeochemical processes (Rush et al. 2003). On reflective (sensu Defeo \& McLachlan 2005) beaches, especially in areas of intense human activity such as the Ligurian Coast, biological processes are mainly related to microbial activities. It has been observed that bacteria are the key player in the benthic community (Covazzi Harriague et al. 2006), though the influence of fungal activity has been observed on the emerged part of the beach (Fabiano et al. 2002). However, in changing environments, where substrate concentrations may vary suddenly, regulatory enzyme expression mechanisms may exhibit a much greater influence on enzymatic activity than bacterial biomass (Rath et al. 1993) because enzyme activity response to nutrient variability is more rapid than changes in biomass and species composition (Sala et al. 2001).

The present study focused on the distribution and seasonal variation of extracellular enzymes (leucine aminopeptidase, $\beta$-glucosidase and alkaline phosphatase) devoted to the recycling of organic matter, and on potential organic substrate availability on a sandy beach subjected to tourism all year round, albeit with notable increases during the summer season. Moreover, this study also considered the eventual dif- ferences of the above-mentioned processes between the western part of the beach, occupied by the structures of a private swimming establishment undergoing major reconstruction work (impacted area), and the eastern, more natural part (reference area).

\section{MATERIALS AND METHODS}

Study site and sampling procedure. Samples were collected from a pocket beach (about $300 \mathrm{~m}$ in length) called Baia Blu on the eastern coast of Liguria (Italy) facing the Ligurian Sea (NW Mediterranean) (Fig. 1). Sampling took place during 4 campaigns in May, July and November 2005 and March 2006. This beach is frequently used by tourists, especially in the months from May to September, and the warm weather of 2005 - which lasted until November - prolonged the bathing season. The southerly oriented beach is delimited by a steep cliff (about $30 \mathrm{~m}$ in height) with typical Mediterranean flora that never encroaches onto the beach. The coastal current flows from east to west. The area is characterised by low wave heights $(<1 \mathrm{~m})$, especially during the sampling period when we observed no rough sea or wind events that could cause modifications (e.g. erosion) of the shoreline. The Ligurian Sea is a microtidal environment with tide excursions of less than $20 \mathrm{~cm}$; therefore, the sand-water exchange depends almost entirely on wave action.

Baia Blu has maintained its natural features for a long time because it is naturally protected from direct urban and harbour effluents. Nevertheless, during recent years, the western side of the beach has been partially occupied by the structures of a private swimming establishment providing the usual tourist facili-

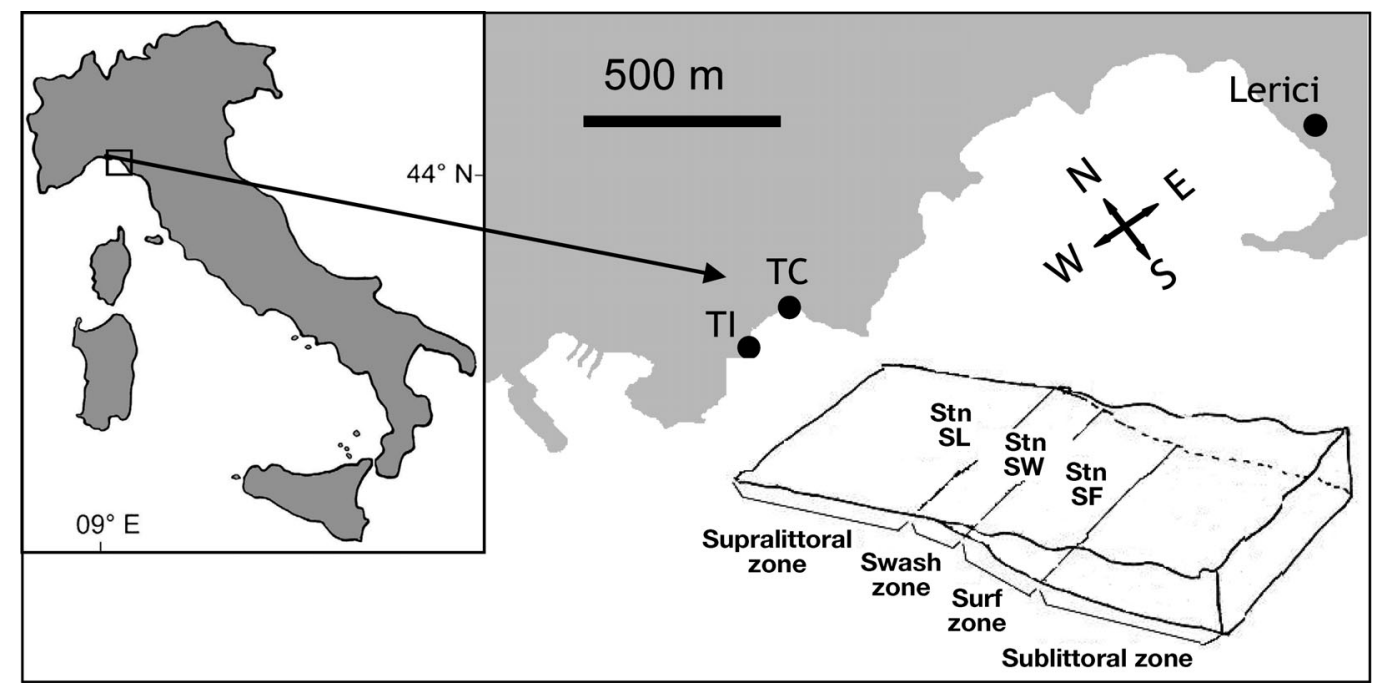

Fig. 1. Sampling area $\left(44^{\circ} 05^{\prime} \mathrm{N}, 9^{\circ} 54^{\prime} \mathrm{E}\right)$, location of Transects TI and TC and positions of the 3 stations (Stns SL, SW and SF) along the transects 
ties and, consequently, the beach is often cleaned. Moreover, during the sampling period, the private area underwent major reconstruction work to improve the quality and quantity of the tourist facilities, resulting in notable modifications to the cliff, namely the excavation of a large portion of the rock and the production of both fine and coarse rocky detritus that was often observed next to the sampling sites.

The beach was sampled along 2 transects, TI and TC, which were perpendicular to the shoreline (Fig. 1; Table 1 reports the main environmental conditions and the intensity of human pressure) and about $200 \mathrm{~m}$ apart. Transect TC was not heavily influenced by the construction work and cleaning procedures taking place in the private area due to the direction of the coastal current; this suggests that this transect may be a natural control, while Transect TI was directly affected by the associated human activities.

Three sampling stations were located along each transect (Fig. 1), starting at the emerged beach: Stn SL (supralittoral), ca. 1 to $1.5 \mathrm{~m}$ from the waterline; Stn SW, in the swash zone; and Stn SF, in the surf zone, ca. 1 to $1.5 \mathrm{~m}$ beyond the waterline at a depth of ca. $0.5 \mathrm{~m}$.

Pre-washed ( $\mathrm{HCl} 0.1 \mathrm{~N}$ ) plastic containers were used to manually collect the seawater from the 2 surf zones for the determination of nutrient concentrations.

Sediment was collected in plexiglass tubes (inner diameter $5 \mathrm{~cm}$ ) down to a depth of $15 \mathrm{~cm}$. Slices of the sediment cores were made by isolating the layers 0 to 2 , 2 to 5,5 to 10 and 10 to $15 \mathrm{~cm}$. The samples for enzymatic activity determinations were immediately slurried in $0.2 \mu \mathrm{m}$ pore-filtered and autoclaved seawater with artificial substrates (see below for details) and stored at in situ temperature in the dark. The sediment samples for organic matter determination were stored at $-20^{\circ} \mathrm{C}$ until analysis in the laboratory. Sediment (1 to $2 \mathrm{~g}$ ) for the bacterial counts was taken in triplicate by means of sterile plastic tubes. Each sample was placed in $5 \mathrm{ml}$ of $0.2 \mu \mathrm{m}$ filtered seawater, fixed with $0.2 \mu \mathrm{m}$ filtered, buffered formaldehyde ( $2 \%$ final concentration) and stored at $4{ }^{\circ} \mathrm{C}$ in the dark until further analysis.

Grain size. The grain size analysis was performed following Buchanan \& Kain (1971); briefly, sediments were sieved ( 9 mesh sizes from 3.35 to $0.063 \mathrm{~mm}$ ) after $\mathrm{H}_{2} \mathrm{O}_{2}$ treatment and drying $\left(60^{\circ} \mathrm{C}, 48 \mathrm{~h}\right)$.

Enzymatic activity determination, chemical, biochemical and bacterial analyses. Enzymatic activity (saturation velocity with artificial substrate, final concentrations of $800 \mu \mathrm{M}$ as determined by substrate saturation experiments) was measured using the following model substrates: 4-methylumbelliferyl $\beta$-D-glucoside, 4-methylumbelliferyl phosphate and L-leucine 7 amido-4-methylcoumarin hydrochloride, respectively, for $\beta$-glucosidase (BG), alkaline phosphatase (AP) and leucine aminopeptidase (LA). The artificial substrates were dissolved in $0.2 \mu \mathrm{m}$ pore-filtered (Puradisc TM25AS) and autoclaved seawater. Each enzymatic determination was carried out in duplicate on sediment subsamples of about 0.5 to $1 \mathrm{~g}$ (dry weight) in $5 \mathrm{ml}$ volume of $0.2 \mu \mathrm{m}$ pore-filtered (Puradisc TM25AS) and autoclaved seawater with substrates. The control samples (sample sediments immediately stopped with formalin) were processed to determine interference due to the manipulation rather than the sample activity. All the samples were incubated in the dark under in situ temperature conditions (from 15 to $25^{\circ} \mathrm{C}$, depending on the season) for 6 to $8 \mathrm{~h}$. Immediately after incubation, fluorescence was detected with a Perkin Elmer LS50B spectrofluorometer calibrated with 4-methylumbelliferone and 7-amino-4-methylcoumarin solutions. Enzymatic activity ( $\mathrm{nmol} \mathrm{g}{ }^{-1} \mathrm{~h}^{-1}$ ) was normalised to sediment dry weight after desiccation at $60^{\circ} \mathrm{C}$ for $24 \mathrm{~h}$.

Inorganic nutrient (nitrite+nitrate and ortophosphate) concentrations of the seawater in front of the 2 transects were determined following Hansen \& Grasshoff (1983) with a Nutrient Probe Analyser SYSTEA

For the determination of organic matter, protein and carbohydrate contents were estimated according to Hartree (1972) and Dubois et al. (1956), respectively. A Jasco V-500 spectrophotometer was calibrated with bovine serum albumin (BSA) and D(+)glucose solutions. Protein N was calculated by multiplying by 6.25 . Labile organic phosphorus was determined following the first step of the sequential extraction (SEDEX) proposed by Ruttenberg (1992). Briefly, sediment samples ( 3 to $5 \mathrm{~g}$ ) were shaken for $2 \mathrm{~h}$ at $50^{\circ} \mathrm{C}$ in a $1 \mathrm{M} \mathrm{MgCl}_{2}$ solution in order to detach the loosely sorbed $\mathrm{P}$ from the sediment. The supernatant was then treated with an oxidising solution $\left(\mathrm{K}_{2} \mathrm{~S}_{2} \mathrm{O}_{8}\right.$, Koroleff 1983) in order to transform all the $\mathrm{P}$ into inorganic phosphates, which were then detected following Hansen \& Grasshoff (1983) with a Nutrient Probe Analyser SYSTEA. The photosynthetic pigments (chlorophyll a [chl a] and phaeopigments) were extracted according to Lorenzen \& Jeffrey (1980). The Perkin Elmer LS50B spectrofluorometer was calibrated with a solution of chl a from Anacystis nidulans.

The organic matter concentrations were normalised to sediment dry weight after desiccation at $60^{\circ} \mathrm{C}$ for

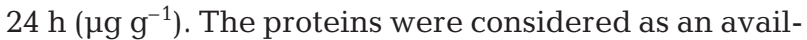
able substrate for the proteolytic enzymes represented by LA, while the carbohydrates included the specific substrates for BG (cellulose). The labile organic phosphorus and inorganic phosphate concentrations were related to AP.

Bacteria counts were performed with epi-fluorescence microscopy (Zeiss Universal Microscope) using $0.2 \mu \mathrm{m}$ black Nuclepore filters after acridine orange 
staining (Hobbie et al. 1977). The contribution of different size classes to the total bacterial density was evaluated by assigning bacteria to different size classes according to Palumbo et al. (1984) (small-size bacteria: $<0.065 \mathrm{\mu m}^{3}$; medium-size bacteria: 0.065 to $0.320 \mathrm{\mu m}^{3}$; large-size bacteria: 0.320 to $0.780 \mathrm{\mu m}^{3}$ ), and by converting the biovolume into biomass carbon con-

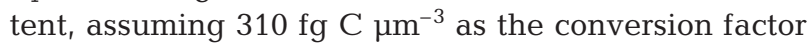
(Fry 1990). We chose this conversion factor in order to compare the results with previous studies on Ligurian beaches; nonetheless, very different coefficients may be found in the literature. In order to calculate the $\mathrm{N}$ content of the bacteria, we used a $\mathrm{C}: \mathrm{N}$ ratio of 6.4 (Fukuda et al. 1998). The total bacterial number $\left(\times 10^{8}\right.$ cells $\mathrm{g}^{-1}$ ) and biomass ( $\mu \mathrm{C} \mathrm{C}^{-1}$ ) were normalised to dry weight after desiccation at $60^{\circ} \mathrm{C}$ for $24 \mathrm{~h}$.

Statistics. We tested the differences between the different layers of the sediment, the seasonal trends of each station (namely the successive seasons) and the 2 transects during the different seasons with Student's $t$-test. To test the relationships between the various parameters, a Spearman-rank correlation analysis was performed. We used the PRIMER $6 \beta$ program package to perform cluster analyses of the normalised data to reveal similarities between stations. Similarities were calculated using Euclidean distances. The complete group linkage method was used to calculate dendrograms. Similarity percentage analysis (SIMPER) was used to analyse parameter dominance.

\section{RESULTS}

\section{Sediment characteristics}

The entire beach was characterised by coarse sediments (Table 1). The average grain size was $1.4 \pm$ $0.4 \mathrm{~mm}$, with a minimum of $0.2 \mathrm{~mm}$ (March, Transect TI, Stn SL) and a maximum of $1.7 \mathrm{~mm}$ (March, Transect TC, Stn SL). An increase in the finer fraction observed in March at Stn SL of Transect TI was related to the work in progress on the private part of the beach. The sediment texture did not show significant differences between transects or among seasons. However, it displayed significant differences between Stns SW and $\mathrm{SL}(t$-test, $\mathrm{p}=0.018)$ and SW and SF ( $t$-test, $\mathrm{p}=0.016)$ of Transect $\mathrm{TC}_{i}$ all the Transect TI stations were similar.

\section{Inorganic seawater nutrients}

The inorganic nutrients of the seawater (Table 1) showed similar seasonal trends for both the $\mathrm{N}$ and $\mathrm{P}$ nutrients. However, only the nitrite+nitrate trends of the 2 sampling stations were significantly correlated ( $\mathrm{p}<0.05$ ), possibly owing to the small data set. The highest values were recorded in November, when the $P$ concentrations were significantly higher $(0.20$ and $0.18 \mu \mathrm{M}$ for Transects $\mathrm{TC}$ and $\mathrm{TI}$, respectively) than

Table 1. Environmental and morphological characteristics and anthropogenic pressure evaluation of the 2 transects. TSM: total suspended matter; OSM: organic suspended matter; $\mathrm{NO}_{x}$ : nitrate+nitrite; $\mathrm{PO}_{4}$ : phosphate. Intensity of anthropogenic pressure varies from absent (-) to very heavy (++++)

\begin{tabular}{|c|c|c|c|c|c|c|c|c|}
\hline Month & $\begin{array}{c}\text { Water } \\
\text { temp. }\left({ }^{\circ} \mathrm{C}\right)\end{array}$ & $\begin{array}{c}\text { Sediment } \\
\text { texture (slope) }\end{array}$ & $\begin{array}{l}\text { Anthropogenic } \\
\text { bathers }\end{array}$ & $\begin{array}{l}\text { pressure } \\
\text { works }\end{array}$ & $\begin{array}{c}\text { TSM } \\
\left(\mathrm{mg} \mathrm{l}^{-1}\right)\end{array}$ & $\begin{array}{c}\text { OSM } \\
(\%)\end{array}$ & $\begin{array}{l}\mathrm{NO}_{x} \\
(\mu \mathrm{M})\end{array}$ & $\begin{array}{l}\mathrm{PO}_{4} \\
(\mu \mathrm{M})\end{array}$ \\
\hline \multicolumn{9}{|c|}{ Transect TC } \\
\hline May & 18.4 & $\begin{array}{l}\text { Gravel } \\
(19.4 \%)\end{array}$ & + & - & $6.0 \pm 0.4$ & $38 \pm 2$ & $0.7 \pm 0.1$ & $0.09 \pm 0.04$ \\
\hline Jul & 25.8 & $\begin{array}{c}\text { Coarse sand } \\
(17.6 \%)\end{array}$ & ++++ & - & $6.8 \pm 0.0$ & $32 \pm 2$ & $0.2 \pm 0.1$ & $0.07 \pm 0.02$ \\
\hline Nov & 18.5 & $\begin{array}{c}\text { Gravel } \\
(17.6 \%)\end{array}$ & ++ & - & $3.9 \pm 0.0$ & $32 \pm 3$ & $3.1 \pm 0.4$ & $0.18 \pm 0.03$ \\
\hline Mar & 11.4 & $\begin{array}{c}\text { Gravel } \\
(21.3 \%)\end{array}$ & + & - & $5.4 \pm 2.8$ & $33 \pm 20$ & $1.7 \pm 0.3$ & $0.09 \pm 0.01$ \\
\hline \multicolumn{9}{|c|}{ Transect TI } \\
\hline May & 18.4 & $\begin{array}{l}\text { Gravel } \\
(17.6 \%)\end{array}$ & - & ++ & $40.4 \pm 0.8$ & $9 \pm 2$ & $0.6 \pm 0.0$ & $0.13 \pm 0.01$ \\
\hline Jul & 25.8 & $\begin{array}{c}\text { Gravel } \\
(10.5 \%)\end{array}$ & ++++ & + & $7.6 \pm 0.3$ & $25 \pm 0$ & $0.3 \pm 0.2$ & $0.12 \pm 0.01$ \\
\hline Nov & 18.5 & $\begin{array}{l}\text { Gravel } \\
(10.5 \%)\end{array}$ & + & + & $5.1 \pm 0.3$ & $25 \pm 1$ & $2.5 \pm 0.5$ & $0.20 \pm 0.04$ \\
\hline Mar & 11.4 & $\begin{array}{l}\text { Mid sand } \\
(5.2 \%)\end{array}$ & - & ++ & $6.2 \pm 1.8$ & $11 \pm 7$ & $1.8 \pm 0.1$ & $0.08 \pm 0.02$ \\
\hline
\end{tabular}


during the other seasons (from 0.07 to $0.13 \mu \mathrm{M}, t$-test, $\mathrm{p}=0.013)$. The nitrite+nitrate concentrations of November and March (on average 2.8 and $1.7 \mu \mathrm{M}$, respectively) were significantly higher than those of May and July (values from 0.22 to $0.72 \mu \mathrm{M}$, $t$-test, $\mathrm{p}=$ 0.0009).

\section{Organic matter}

Owing to the homogeneity of the sedimentary texture of the beach, no significant differences were recorded between the sedimentary layers. The trends with depth seldom showed increases in the deeper layer (10 to $15 \mathrm{~cm}$ ), probably due to the retention of organic materials, namely proteins and carbohydrates that were not drained by the waves. These trends were especially observable during May and July. The continuous influence of wave action was confirmed by the chl a distributions with depth in the sediments, also generally homogeneous in the exposed 0 to $2 \mathrm{~cm}$ layer of Stn SL and in the dark, deep layers.
Autotrophic organic matter

Chl a (Table 2) showed significant seasonal variations ( $t$-tests, $\mathrm{p}<0.003$ and $\mathrm{p}<0.036$ for chl $a$ and phaeopigments, respectively, except from July to November along Transect TI). The values were generally quite low, ranging from 35.8 to $189.4 \mathrm{ng} \mathrm{g}^{-1}$ along Transect TC and from 24.1 to $178.6 \mathrm{ng} \mathrm{g}^{-1}$ along Transect TI. The highest seasonal trend values (average of all the transect data) were observed in November (up to $170 \mathrm{ng} \mathrm{g}^{-1}$ along Transect TC and $120 \mathrm{ng} \mathrm{g}^{-1}$ along Transect TI), and the lowest in May (from $30 \mathrm{ng} \mathrm{g}^{-1}$ along Transect TI to $40 \mathrm{ng} \mathrm{g}^{-1}$ along Transect TC). The highest average chl a:phaeopigment ratio values were observed in November (up to 1.5), and the lowest in July ( 0.5 and 0.4 for Transects TC and TI, respectively). The organic $\mathrm{C}$ bulk of the sediments was calculated as the sum of the contribution of protein, carbohydrate and chl a (using conversion factors of $0.49,0.4$ and 40 , respectively, as reported by Misic et al. 2002 and de Jonge 1980). The contribution of the chl a $\mathrm{C}$ ranged between 4.6 and $32.0 \%$ for Transect TC and between 3.5 and $32.8 \%$ for Transect TI. No significant differ-

Table 2. Mean values of pigments, organic matter content and enzymatic activity in the sediments of Baia Blu, Italy. Phaeo: phaeopigments; LA: leucine aminopeptidase; BG: $\beta$-glucosidase; AP: alkaline phosphatase

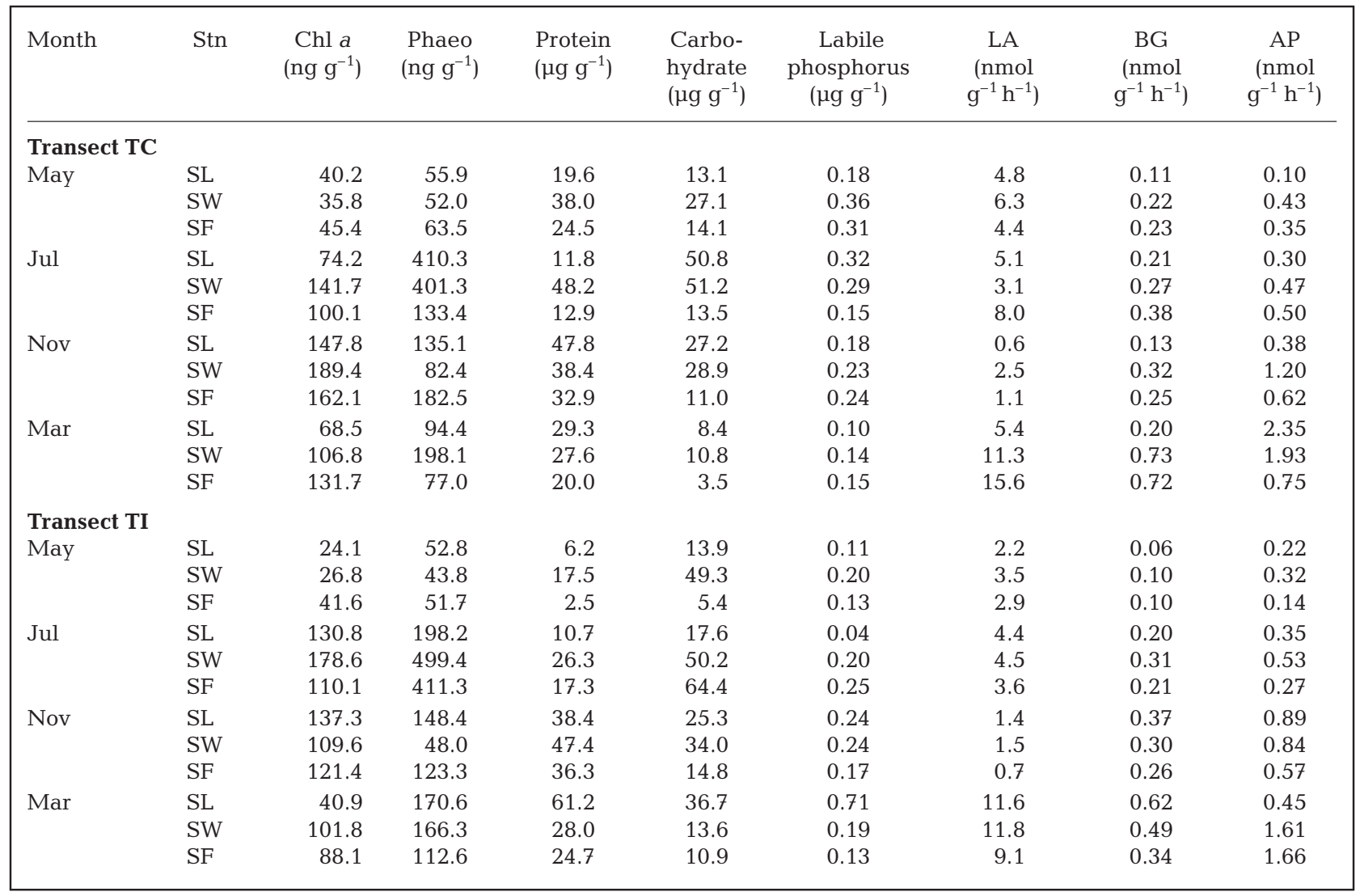



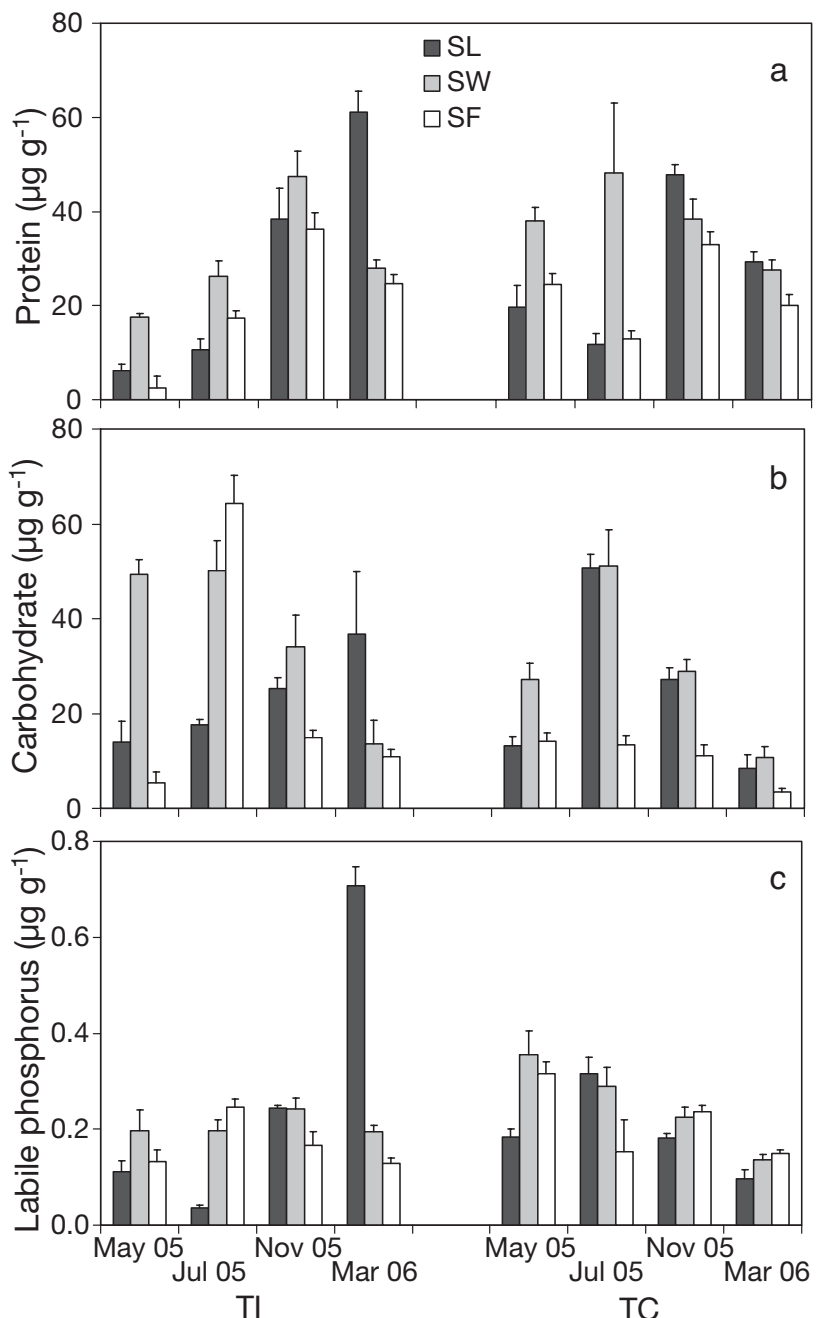

Fig. 2. Mean values of (a) protein, (b) carbohydrate and (c) labile phosphorus (bottom) at each station of the 2 transects (TI and TC). Bars denote SD among values recorded in different layers at each station

ences were observed between the 2 transects when comparing all the data for each transect or the data for each season. Generally, the highest chl a contribution was observed at Stn SF of each transect (mean values of $22.7 \%$ for Transect TC and $19.7 \%$ for Transect TI).

Protein, carbohydrate and labile phosphorus contents

The mean protein, carbohydrate and labile phosphorus content of the sediments is presented in Fig. 2 \& Table 2. Proteins ranged from 11.8 to $48.2 \mu \mathrm{g} \mathrm{g}^{-1}$ along Transect TC and from 2.5 to $61.2 \mu \mathrm{g} \mathrm{g}^{-1}$ along Transect TI, with the highest mean values during November and the lowest during July (TC) and May (TI). The carbohydrates ranged from 3.5 to $51.2 \mathrm{\mu g} \mathrm{g}^{-1}$ along Transect TC and from 5.4 to $64.4 \mu g^{-1}$ along Tran- sect TI, with the lowest mean values for both the transects observed during March. The protein:carbohydrate ratio was generally higher at Transect TC than Transect TI, with higher values during November and March (up to 4.2 on average for Transect TC during the autumn) and the lowest during summer ( 0.5 and 0.7 for Transects TI and TC, respectively). The ratio was also notably low at Transect TI in May (on average 0.4).

The labile phosphorus ranged from 0.10 to $0.36 \mu \mathrm{g}$ $\mathrm{g}^{-1}$ along Transect TC and 0.04 to $0.71 \mu^{-1} \mathrm{~g} \mathrm{~g}^{-1}$ along Transect TI, with a decreasing trend from May 2005 to March 2006 at Transect TC. The lowest values at Transect TI were observed during May and July; subsequently, the labile phosphorus content increased.

Significant variations were recorded on a seasonal basis for each station of Transect TC. Proteins changed significantly from July to November and from November to March ( $t$-tests, $\mathrm{p}<0.026$ at most), carbohydrates were always variable throughout the seasons ( $t$-tests, $\mathrm{p}<0.04$ at most) and labile phosphorus changed from November to March and March to May ( $t$-tests, $p$ < 0.001 at most). Along Transect TI, proteins and carbohydrates changed significantly from May to July and from July to November ( $t$-tests, $p<0.047$ at most), while labile phosphorus remained unchanged.

Owing to these irregular variations, the differences between the 2 transects were often not significant. The protein content was higher along Transect TC only during May ( $t$-test, $\mathrm{p}<0.001)$, while the carbohydrate content was higher along Transect TI only during March ( $t$-test, $\mathrm{p}=0.03)$. In comparison, the labile phosphorus content was significantly higher at Transect TC in May and July, and lower in March (t-tests, $\mathrm{p}<0.048$ at most).

\section{Enzymatic activity}

There were no significant differences in enzymatic activity in the different sedimentary layers (Figs. 3 to 5), suggesting a general homogeneity in the first $15 \mathrm{~cm}$ of the beach sediment. Table 2 summarises the mean values during the sampling periods.

The LA values were, on average, 5.7 (0.2 to 20.0) $\mathrm{nmol} \mathrm{g}{ }^{-1} \mathrm{~h}^{-1}$ along Transect TC and 4.8 (0.5 to 14.7 ) $n m o l ~ ~^{-1} \mathrm{~h}^{-1}$ along Transect TI. The highest values were recorded during March (mean transect values more than $10 \mathrm{nmol} \mathrm{g}^{-1} \mathrm{~h}^{-1}$ for both transects), the lowest during November (1.43 and $1.22 \mathrm{nmol} \mathrm{g}^{-1} \mathrm{~h}^{-1}$ for Transects $\mathrm{TC}$ and TI, respectively). The BG values were, on average, 0.31 (0.03 to 0.92$) \mathrm{nmol} \mathrm{g}^{-1} \mathrm{~h}^{-1}$ for Transect TC and 0.28 ( 0.05 to 0.78$) \mathrm{nmol} \mathrm{g}^{-1} \mathrm{~h}^{-1}$ for Transect TI. The highest values were recorded during March (mean transect values 0.55 and $0.48 \mathrm{nmol} \mathrm{g}^{-1} \mathrm{~h}^{-1}$ for Transects TC and $\mathrm{TI}$, respectively), the lowest during May (0.19 and 


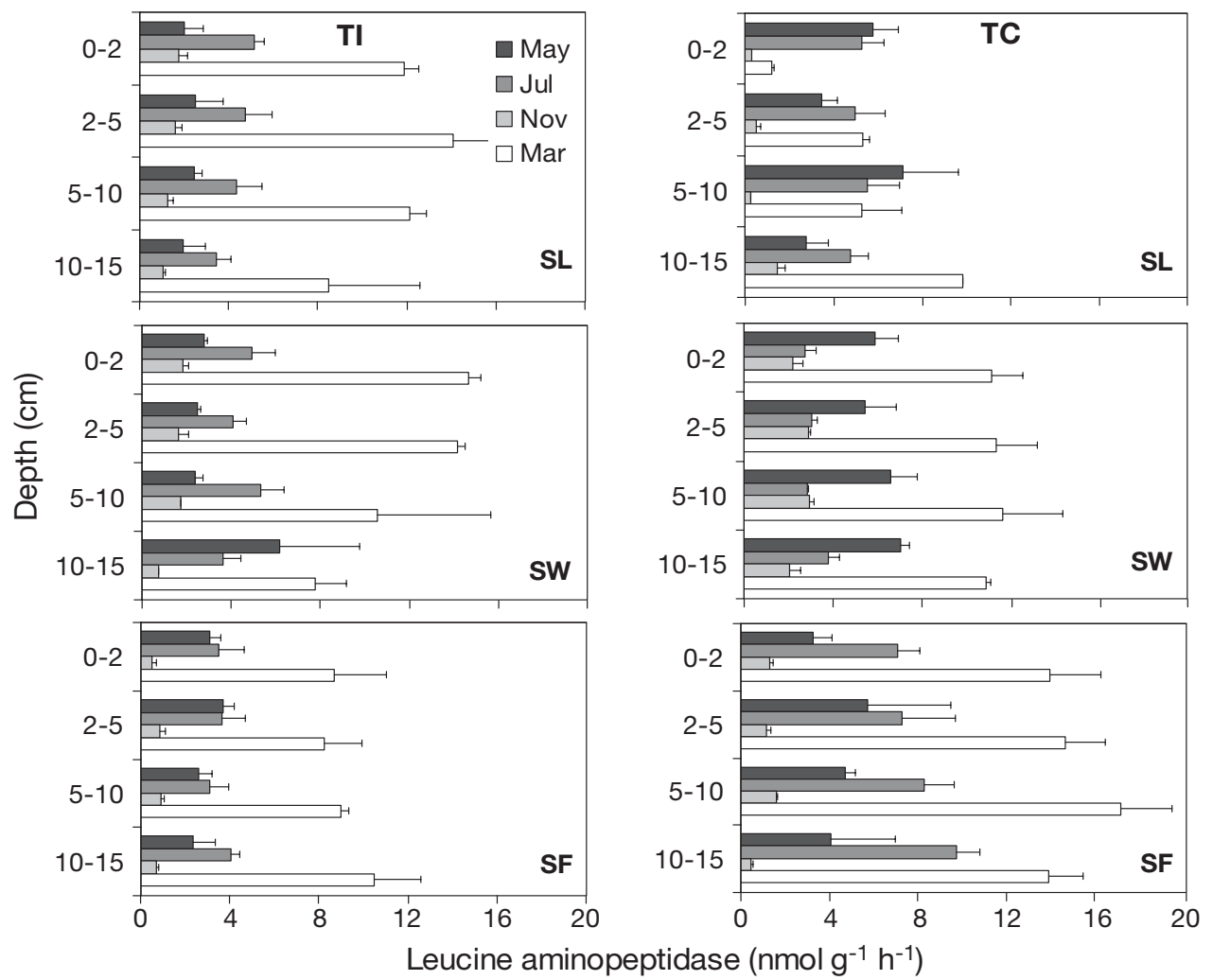

Fig. 3. Leucine aminopeptidase (LA) activity trends with depth in sediment from 3 stations (Stns SL, SW and SF) of the 2 transects (TI and (TC). SD are given

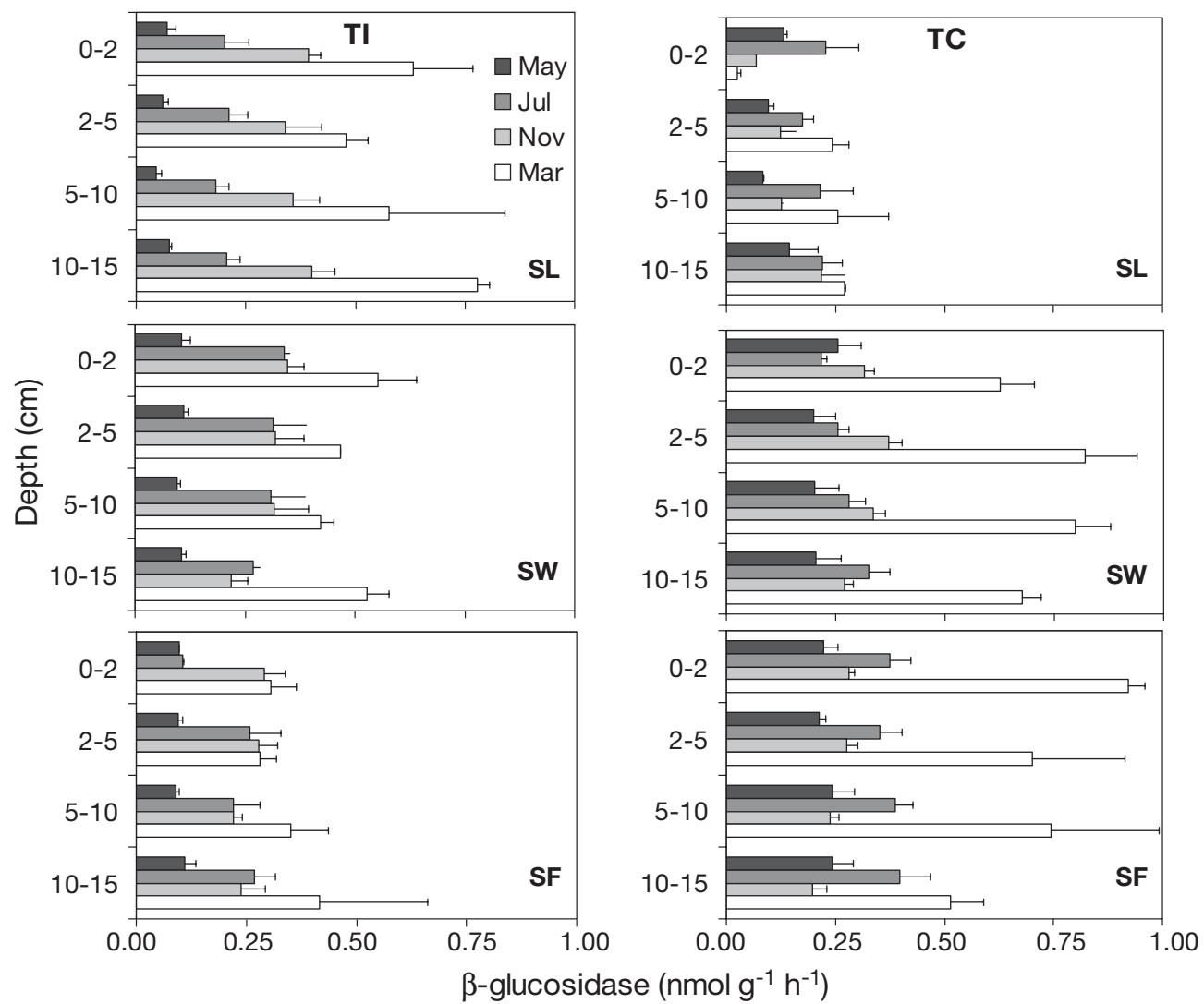

Fig. 4. $\beta$-glucosidase (BG) activity trends with depth in sediment from 3 stations (Stns SL, SW and SF) of the 2 transects (TI and TC). SD are given 


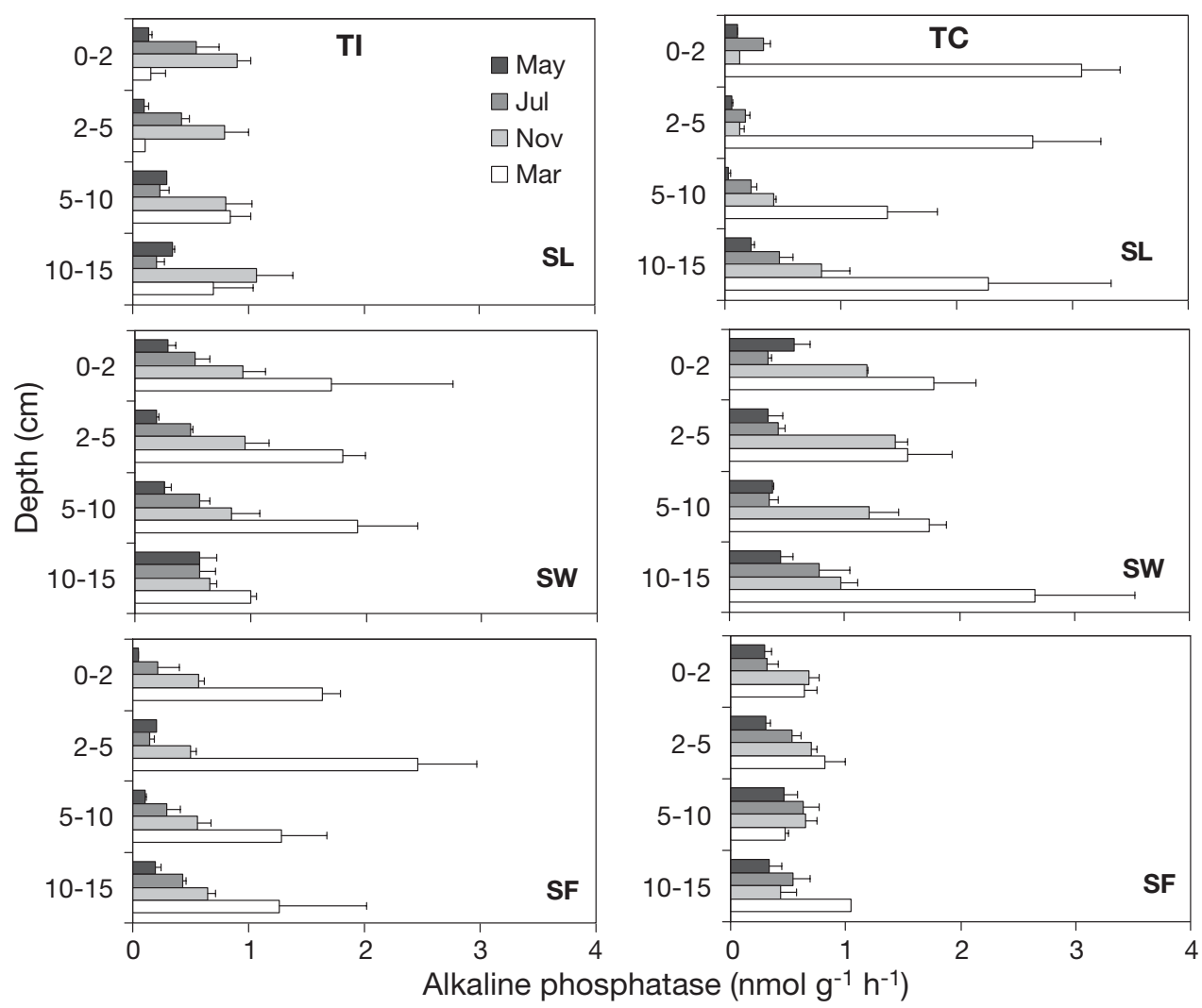

Fig. 5. Alkaline phosphatase (AP) activity trends with depth in sediment from 3 stations (Stns SL, SW and SF) of the 2 transects (TI and TC). SD are given

$0.09 \mathrm{nmol} \mathrm{g}^{-1} \mathrm{~h}^{-1}$ for Transects TC and TI, respectively). The LA:BG ratio values showed a decrease from May (more than 30 for both transects) to November ( 6 and 4 for Transects TC and TI, respectively).

The AP values were, on average, 0.78 (0.03 to 3.08) nmol $\mathrm{g}^{-1} \mathrm{~h}^{-1}$ for Transect TC and 0.66 (0.05 to 2.46) $\mathrm{nmol} \mathrm{g}^{-1} \mathrm{~h}^{-1}$ for Transect TI. The highest values were recorded during March (mean transect values 1.68 and $1.24 \mathrm{nmol} \mathrm{g}^{-1} \mathrm{~h}^{-1}$ for Transects TC and TI, respectively), the lowest during May (0.30 and $0.23 \mathrm{nmol} \mathrm{g}^{-1} \mathrm{~h}^{-1}$ for Transects TC and TI, respectively).

The 2 transects showed notable variability between nearly all seasons ( $t$-tests, $\mathrm{p}<0.045$ at most). The comparison of the transects highlighted significant differences for LA and BG during May ( $t$-test, $p<0.001$ at most), and for BG during November ( $t$-test, $\mathrm{p}=0.03$ ). There was no significant variation in AP between transects.

\section{Bacterial parameters}

There were no significant bacterial differences among layers, seasons and transects. However, we observed a rise in the abundances along both transects during autumn, with values up to 1.79 and $1.49 \times 10^{8}$ cells $\mathrm{g}^{-1}$ for Stns SW of Transects TI and TC, respectively (Fig. 6). The bacterial abundance of Stn SW $(0.9$ and $1.12 \times 10^{8}$ cells g $^{-1}$ for Transects TI and TC, respectively) was, on average, higher than that of all the other stations (Stn SL: 0.89 and $0.70 \times 10^{8}$ cells ${ }^{-1}$ for Transects TI and TC, respectively; Stn SF: 0.54 and $0.98 \times$ $10^{8}$ cells $\mathrm{g}^{-1}$ for Transects $\mathrm{TI}$ and $\mathrm{TC}$, respectively).

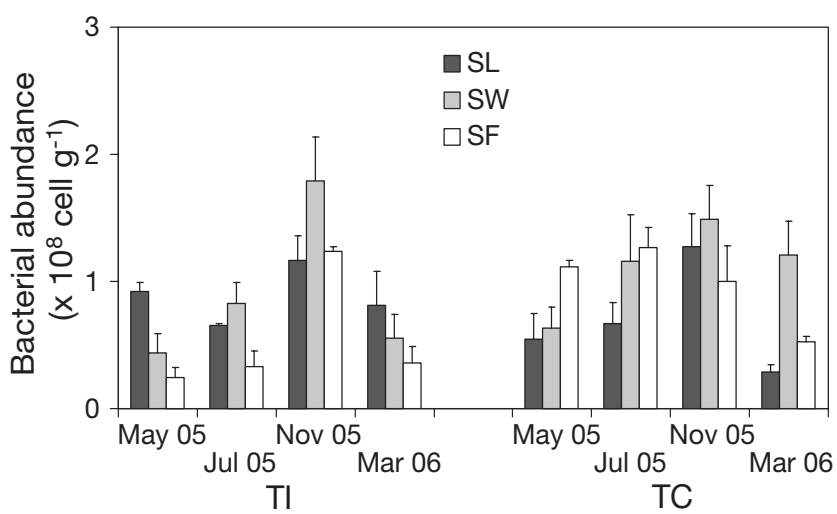

Fig. 6. Mean values of bacterial abundance at each station (Stns SL, SW and SF) of the 2 transects (TI and TC). Bars denote SD among values recorded in different layers at each station 
Bacterial biomass followed the trends of the bacterial abundances, with higher values up to $10.0 \mu^{-\mathrm{C} \mathrm{g}^{-1}}$ at Stn SW of Transect TI and up to 6.3 to $7.1 \mu \mathrm{g} \mathrm{C} \mathrm{g}^{-1}$ at Stns SW and SL of Transect $\mathrm{TC}$, respectively, during November; yet, the highest value for Transect TC was recorded at Stn SF during July $\left(8.0 \mu \mathrm{g} \mathrm{C} \mathrm{g}^{-1}\right)$. The lowest values for each parameter were recorded during March $\left(0.2 \times 10^{8}\right.$ cells $\mathrm{g}^{-1}$ for abundance and $1.5 \mu \mathrm{g} \mathrm{C}$ $\mathrm{g}^{-1}$ for biomass at Stn SL of Transect TC), but Transect TI also comprised low values during May (down to $0.24 \times 10^{8}$ cells $\mathrm{g}^{-1}$ for abundance and $1.3 \mu \mathrm{g} \mathrm{C} \mathrm{g}^{-1}$ for biomass at Stn SL). The calculated bacterial $\mathrm{N}$ contribution to protein $\mathrm{N}$ ranged from 9.4 to $94.2 \%$ along Transect TC and from 12.7 to $94.0 \%$ along Transect TI. Along Transect TC, the highest mean contribution was observed during July (57.1\%), and that along Transect TI during May (69.6\%). In comparison, the lowest values $(25.4$ and $15.2 \%$ for Transects TC and TI, respectively) were recorded during March.

The bacterial cell size ranged from 4.0 to 6.3 (on average 5.1) $\mu \mathrm{g} \mathrm{C} \times 10^{-8}$ cell $^{-1}$, with lower values along Transect TI during May (for Stns SL and SW, these values were significantly lower than those recorded in the same places during the other seasons, $t$-tests, $\mathrm{p}<0.03$ ) and along Transect TC during March and November. Significantly higher values ( $t$-test, $\mathrm{p}<0.003)$ were recorded along both transects during July.

\section{Multivariate statistical analysis}

The cluster analysis performed on the organic matter (chl $a$, phaeopigment, protein, carbohydrate and labile phosphorus content), bacterial abundance and enzy- matic activities (Fig. 7) showed a general uniformity for stations in the same season, except for summer. The division of the stations into 2 groups in this season suggested the occurrence of different factors regulating the organic matter and the enzymatic activity. The principal parameters driving these differences (SIMPER analysis) were derived from a comparison of the organic matter of spring and summer and summer and autumn (the contribution of phaeopigment was ca. $40 \%$ and that of carbohydrate ca. $25 \%$; chl a was relevant only in the variation between spring and summer [17\%], and proteins contributed less than 15\%). In comparison, enzymatic activity drove the differentiation in the autumn-winter and winter-spring comparisons (LA explaining from 15 to $32 \%$, BG from 16 to $23 \%$ and AP from 15 to $23 \%$ ).

\section{DISCUSSION}

\section{Major trophic sources and their potential exploitation pathways}

Generally the swash area of reflective beaches is strongly influenced by the seawater penetrating the surface layers of the beach as waves (Defeo \& McLachlan 2005). Materials and energy may, therefore, have an allochthonous origin. Carbohydrates are usually considered refractory because their main constituent is structural polymers, characterised by a long life and persistence within the organic matter bulk even if degradation and decomposition are in progress, and they may be used as indicators of allochthonous input (Danovaro et al. 1999). At Baia Blu the carbohydrate

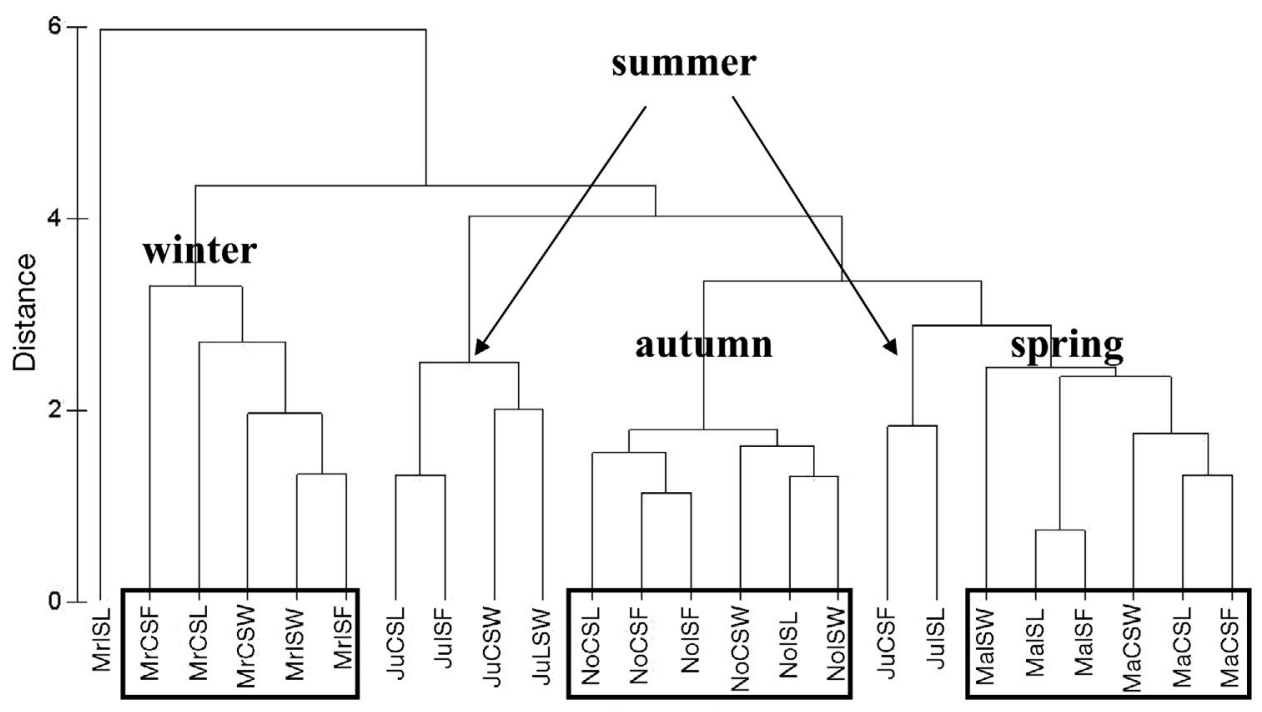

Fig. 7. Cluster analysis based on organic matter content and extracellular enzymatic activities. Sampling sites are identified by the seasonal period (Ma: May; Ju: July; No: November; Mr: March), the transect (C: Transect TC; I: Transect TI) and position along the transect (SL, SW and SF) 
fraction was significantly related to the degraded fraction of the primary biomass, namely the phaeopigments, indicating that this kind of glucide is derived from aged organic matter. An adverse effect of the refractory organic matter, i.e. the slowing of the organic matter recycling processes, was suggested by the absence of positive correlations between carbohydrates and the 2 degradative enzymatic activities (LA and BG, Table 3). Similarly, Fabiano et al. (2002) found that the carbohydrate content of other Ligurian beaches was inversely correlated to the frequency of bacterial cell division, suggesting a sort of inhibition for the replication activity.

Nevertheless, a structural carbohydrate may sometimes be a trophic resource. At Baia Blu, when the environmental conditions were more favourable and bacteria were supported by larger $N$ sources, the microbial community displayed a notable contribution to glycolitic activity. We found that under the favourable conditions that occurred during the warm November of 2005, the inorganic seawater nutrients were more abundant and could support the $\mathrm{N}$ requirements for metabolism and enzyme synthesis. During this period, the ratio between the 2 enzymes changed at all our sampling stations. The spring processes at Baia Blu were dominated by proteolysis (proteolysis:glycolysis ratio increased to more than 30), in agreement with Podgórska \& Mudryk (2003), who observed the dominance of gelatin-decomposing bacteria ( 85 to $89 \%$ of all the studied strains) on the sandy beach of Sopot (Poland). The relative impor-

Table 3. Significant correlations between parameters of the 2 transects ( $\mathrm{n}=48$ for all parameters). LA: leucine aminopeptidase; BG: $\beta$-glucosidase; AP: alkaline phosphatase

\begin{tabular}{|llrl|}
\hline Parameter 1 & \multicolumn{1}{c}{ Parameter 2 } & r & \multicolumn{1}{c|}{$\mathrm{p}$} \\
\hline Transect TC & & & \\
Chl $a$ & Protein & 0.32 & $<0.05$ \\
Chl $a$ & Bacterial abundance & 0.31 & $<0.05$ \\
Phaeopigments & Carbohydrate & 0.48 & $<0.001$ \\
Protein & LA & -0.41 & $<0.01$ \\
Labile phosphorus & AP & -0.44 & $<0.01$ \\
Carbohydrate & BG & -0.34 & $<0.05$ \\
Carbohydrate & LA & -0.38 & $<0.01$ \\
LA & BG & 0.80 & $<0.001$ \\
BG & AP & 0.33 & $<0.05$ \\
Transect TI & & & \\
Phaeopigments & Carbohydrate & 0.51 & $<0.001$ \\
Protein & Labile phosphorus & 0.54 & $<0.001$ \\
Protein & Bacterial abundance & 0.31 & $<0.05$ \\
Protein & LA & 0.30 & $<0.05$ \\
LA & BG & 0.63 & $<0.001$ \\
LA & AP & 0.48 & $<0.001$ \\
BG & AP & 0.48 & $<0.001$ \\
& & & \\
\hline
\end{tabular}

tance of the 2 trophic microbial systems (namely the fast protein exploitation and the slow refractory glucide exploitation) in the beach environment can change quickly within a few weeks (Misic \& Fabiano 2005). In fact, in autumn, the ratio decreased sharply to values below 5. Sudden changes in environmental conditions are well known in nearshore areas and the dynamics of the sediments can force bacteria to temporarily endure adverse conditions or rapidly follow their optimal niche, quickly developing their adaptive tools (Rusch et al. 2003).

The sudden decrease in LA activity at both transects during November further indicated the strong influence of the sea on the functional processes of the beach. The notable increase in the inorganic nitrogen compounds in the seawater penetrating the surface layers of the beach, namely nitrite+nitrate concentrations, may provide $\mathrm{N}$ to microbes without the use of hydrolytic enzymes. Similarly, Taylor et al. (2003) observed that, in estuarine areas, LA may be partly regulated by inorganic $\mathrm{N}$ limitation. The repression of proteolytic activity may be an adaptation to the strongly oligotrophic natural conditions of Baia Blu, conserving energy and materials. These resources could be redirected to the production of other, more useful enzymes such as the previously mentioned glucosidases.

Although the allochthonous inputs may notably change the beach communities, Rusch et al. (2003) observed that the main part of the microbiota of coastal sediments subjected to intense wave action is closely linked to the sand grains, thus suggesting the occurrence of organised autochthonous communities that produce fresh and labile autochthonous organic materials. The chl a (biomass of the resident phytobenthic community) contribution to the organic matter content of both our sampling transects was about $16 \%$, actually a very high contribution if compared with the values obtained from other Ligurian beaches (<1\%, Misic \& Fabiano 2005; ranging from 2.1 to $2.6 \%$, Covazzi Harriague et al. 2006). At Baia Blu, the organic substrates available for consumption and degradation may mainly originate in the autotrophic biomass.

Focusing on the bacterial parameters, we observed values similar to those obtained from coastal sediments of the Ligurian Sea (Albertelli et al. 1999) and to those recorded for other Ligurian coastal sites (Arenzano beaches) subjected to tourist pressure (Misic \& Fabiano 2005). Covazzi Harriague et al. (2006) observed a notable bacterial contribution to ecological pathways owing to the fact that they have a higher biomass than the metazoans of the Arenzano beaches. Given this observation, bacteria are also likely to have a relevant role at Baia Blu. Leucine 
aminopeptidase has mainly been associated with bacteria (Andersen-Elvehoy \& Thingstad 1991) and its quantitative proportion to the other enzymes was in accordance with the observation that bacteria actually drive the organic matter turnover of the beach. Bacterial abundance did not show significant changes, either spatially or temporally, suggesting that they quickly overcame anthropogenic pressure and seasonal fluctuations under the environmental and trophic conditions, thus confirming their high adaptability to a changing environment such as a beach. Moreover, the seawater flushing the beach sediment might continuously carry allochthonous bacteria to the beach, therefore maintaining a fairly constant abundance even when the beach conditions do not allow bacterial proliferation. Rusch et al. (2003) reported that bacteria belonging to coarsegrained sediment near the shore were similar to those of the nearby muddy sediment.

The bacterial abundance did not fit with any of the enzymatic activities. This is not surprising because enzymatic hydrolysis is generally the first step in bacterial response to substrate enrichment, while an increase in bacterial abundance is a later step and is controlled not only by bottom-up but also by topdown pressure. The lack of significant correlations between AP and bacteria is due to the fact that the enzyme may have many producers, from algae to bacteria to zooplankton (Sala et al. 2001). Gambin et al. (1999) found that in Mediterranean littoral marine ecosystems the cyprid stage of the development of Cirripedes (Crustacea) was significantly involved in AP expression. The crustaceans in the beach sediment and the higher contribution of the autotrophic fraction at Baia Blu than on other beaches (Covazzi Harriague et al. 2006) could have been responsible for the homogeneous values between the transects and also for the higher activity values than those of BG (more than double).

Trends of AP have often been associated with those of inorganic phosphate owing to the fact that the inorganic nutrient inhibits the enzymatic activity (Hoppe \& Ullrich 1999). Therefore, changes in the relative expressions of AP and LA have been utilised to monitor nutrient imbalance in natural and laboratory systems (Sala et al. 2001). We did not find any direct relationship between AP and inorganic P in the beach environment. Instead, similarly to Sala et al. (2001), who attempted to infer N:P ratio values from AP:LA ratio trends, we observed a correspondence between the highest values of the AP:LA ratio and P deficiency. A sudden change in the enzymatic ratio may be a response to P deficiency; therefore, the AP-LA enzymatic system seems to be a useful tool for overcoming limiting conditions.

\section{Anthropogenic vs. natural (seasonal) pressures: which is the driving force?}

At Baia Blu, the human activities in progress did not seem to notably affect the degradation/ remineralisation potential and the content of the degradable substrates. In fact, a cluster analysis highlighted a strong seasonality more than a division into areas. The SIMPER analysis indicated that the springsummer-autumn seasonal fluctuations were driven by the more refractory components of the organic matter (phaeopigments and carbohydrates) and the autumnwinter-spring variations by the enzymatic expression (especially LA).

It is well known that human trampling and beach nourishment severely affect the metazoan component of benthic communities (Brown \& McLachlan 1990). On the other hand, no significant nourishment impact has been detected on the microbial food web of Ligurian beaches (namely bacteria and organic matter, Fabiano et al. 2004), suggesting the rapid recovery of the microbial system. However, although the seasonal variations were more relevant than the presumed human pressure from a quantitative perspective, we observed that the additional work on the private zone of Baia Blu modified the functional relationships between the parameters, in particular those related to the trophic quality of the organic materials and enzymatic hydrolysis.

With regard to the origin of the labile organic matter, Covazzi Harriague et al. (2006) reported that, on other Ligurian beaches during late spring, there was a lack of significant correlations between chl a and proteins when the organic matter content of the sand was high and, on the contrary, the existence of a significant correlation when the organic matter content was low. Although the organic matter content values of the 2 transects of Baia Blu were similar, a significant correlation could be found between the chl a content and the most labile fraction of the organic matter, namely the proteins, only under the natural conditions of Transect TC (Table 3). This relationship was irregular and unpredictable when the impacted area of Transect TI was considered, suggesting that in this area the heterotrophic benthic community is only partially fuelled by trophic resources provided by phytobenthos.

In addition to the generally lower quality of the trophic supply of the sedimentary organic matter of Transect TI (as shown by the protein:carbohydrate ratio) during May, the labile organic matter (the protein and chl a content) was significantly lower along Transect TI than along Transect TC. This may be a consequence of the work on the cliff, which notably changed the environmental features of the Transect TI area by removing all the vegetational cover and pro- 
ducing a lot of detritus. The heavy rains of May could have easily transferred a lot of fine inorganic debris to the beach area and the sea (Table 1), causing mechanical stress to the beach communities and transporting allochthonous refractory organic matter previously embedded in the soil. In fact, we observed a significantly lower value ( $t$-test, $\mathrm{p}=0.01$ ) for the sedimentary protein:carbohydrate ratio along Transect TI (1.3) than along Transect TC (2.1), suggesting an increase in the trophic limitation of the Transect TI communities. One of the consequences of the trophic limitation was the significantly lower cell size of bacteria along Transect TI during May sampling than during the other seasons.

Bacterial abundance showed few correlations with sedimentary organic matter. Along Transect TC the bacterial abundance was significantly correlated to the chl a content (Table 3), confirming an ecological link between the autotrophic and heterotrophic communities under the more natural conditions. We found a very high bacterial $\mathrm{N}$ contribution to the protein $\mathrm{N}$ (compared with the values recorded, for example, by Danovaro et al. 1999 for marine sediments), indicating that the bacteria actually contributed to the labile organic matter bulk of the beach sediments. The high bacterial contribution to the protein content of the sediment $(\sim 57 \%)$ recorded during July depended on the high biomass documented during this period, and was in accordance with the seasonal trends of the organic matter (characterised by lower detrital protein content owing to heterotrophic consumption and a reduction in productive processes), but this might also have been a result of the overcrowding of the beach by beach-goers during summer, as observed in other areas where an increase in allochthonous bacteria of human origin has been recorded in water utilised for swimming (Elmir et al. 2007). In addition, we found significantly larger bacterial cells along both transects during July.

No significant correlations were recorded between bacteria and chl a along Transect TI, but we found a correlation between bacteria and proteins (Table 3). LA was also significantly correlated to its own organic substrate, and the occurrence of a significant correlation between the AP:LA ratio and the proteins $(r=0.34, p<$ $0.05, \mathrm{n}=48$ ) suggested that the activity of both enzymes was required to exploit the available labile organic matter. Hoppe \& Ullrich (1999) suggested the coupling of LA and AP activity in the mesopelagic Indian Ocean when trophic conditions were severe, i.e. when the microbial communities experienced a strict $\mathrm{C}$ limitation but not a P limitation. The enzymatic hydrolysis of even small phosphorylated compounds by AP is considered necessary for organic matter exploitation because it provides combined P from organic compounds, making them available for further exploitation.
Focusing on AP activity, we did not find a significant correlation between this enzyme and the labile phosphorus along Transect TI, whereas we found an inverse, significant correlation along Transect TC (Table 3). Gage \& Gorham (1985) found such a correlation between AP and cellular phosphorus. If the organic $\mathrm{P}$ of the biomass is high, there is no need for AP expression. This suggests that the labile $\mathrm{P}$ we detected along Transect TC was more related to living biomass than to debris, highlighting the fast turnover of $\mathrm{P}$ in the natural beach environment.

In conclusion, although the microbial system was able to react promptly to external pressures such as anthropogenic use and the modification of the beach, thus being quantitatively influenced by natural seasonal fluctuations, we observed some signals of changes in the functional processes, especially those related to the trophic quality of the organic matter and exploitation of the labile components by means of hydrolytic enzymes; moreover, these changes were often related to the bacterial parameters. A slowing of the organic matter recycling may affect the transfer of energy and materials to the higher trophic levels, thus increasing the bottom-up limitation processes on the metazoans and affecting the entire beach food web.

Acknowledgements. We thank Dr. F. Pannacciulli for her logistical support, and the students of the Environmental Sciences course of the University of Genoa (in particular D. Bosticco) who helped us with sampling and laboratory analyses.

\section{LITERATURE CITED}

Albertelli G, Covazzi Harriague A, Danovaro R, Fabiano M, Fraschetti S, Pusceddu A (1999) Differential responses of bacteria, meiofauna and macrofauna in a shelf area (Ligurian Sea, NW Mediterranean): role of food availability. J Sea Res 42:11-26

Alvarez S, Guerrero MC (2000) Enzymatic activities associated with decomposition of particulate organic matter in two shallow ponds. Soil Biol Biochem 32:1941-1951

Andersen-Elvehoy IL, Thingstad TF (1991) Detection of limiting factors for bacterial activity using protease activity. Kiel Meeresforsch Sonderh 8:392-398

Boetius A, Lochte K (1994) Regulation of microbial enzymatic degradation of organic matter in deep-sea sediments. Mar Ecol Prog Ser 104:299-307

Boshker HTS, Cappenberg TE (1998) Patterns of extracellular enzyme activities in littoral sediments of Lake Gooimeer, The Netherlands. FEMS Microbiol Ecol 25:79-86

Brown AC, McLachlan A (1990) Ecology of sandy shores. Elsevier, Amsterdam

Buchanan JB, Kain JM (1971) Measurement of the physical and chemical environment. In: Holme NA, McIntyre AD (eds) Methods for the study of marine benthos. Oxford, Blackwell Scientific Publications, p 30-52

Christian JR, Karl DM (1995) Bacterial ectoenzymes in marine waters: activity ratios and temperature responses in three oceanographic provinces. Limnol Oceanogr 40:1042-1049 
Covazzi Harriague A, Gaozza L, Montella A, Misic C (2006) Benthic communities on a sandy Ligurian beach (NW Mediterranean). Hydrobiologia 571:383-394

Danovaro R, Marrale D, Della Croce N, Parodi P, Fabiano M (1999) Biochemical composition of sedimentary organic matter and bacterial distribution in the Aegean Sea: trophic state and pelagic-benthic coupling. J Sea Res 42: $117-129$

Defeo O, McLachlan A (2005) Patterns, processes and regulatory mechanisms in sandy beach macrofauna: a multiscale analysis. Mar Ecol Prog Ser 295:1-20

de Jonge VE (1980) Fluctuations in the organic carbon to chlorophyll a ratios for estuarine, benthic diatom populations. Mar Ecol Prog Ser 2:345-353

Dubois M, Gilles K, Hamilton JK, Rebers PA, Smith F (1956) Colorimetric method for determination of sugars and related substances. Anal Chem 28:350-356

Elmir SM, Wright ME, Abdelzaher A, Solo-Gabriele HM and 7 others (2007) Quantitative evaluation of bacteria released by bathers in a marine water. Water Res 41:3-10

Fabiano M, Misic C, Moreno M, Salvo VS, Covazzi A (2002) Ecological features of Ligurian beaches exposed to different hydrodynamic forcing. In: Ozhan E (ed) Proc Int MEDCOAST Workshop on Beach Management in the Mediterranean and the Black Sea: dynamics, regeneration, ecology and management. 24-27 October 2002, Kusadasi, Turkey, p 201-213

Fabiano M, Marin V, Misic C, Moreno M, Salvo VS, Vezzulli L (2004) Sedimentary organic matter and bacterial community in microtidal mixed beaches of the Ligurian Sea (NW Mediterranean). Chem Ecol 20:423-435

Fry JC (1990) Direct methods and biomass estimation. In: Grigorova R, Norris JR (eds) Methods in microbiology. Techniques in microbial ecology. Academic Press, London, $\mathrm{p}$ 41-85

Fukuda R, Ogawa H, Nagata T, Koike I (1998) Direct determination of carbon and nitrogen contents of natural bacterial assemblages in marine environments. Appl Environ Microbiol 64:3352-3358

Gage MA, Gorham E (1985) Alkaline phosphatase activity and cellular phosphorus as an index of the phosphorus status of phytoplankton in Minnesota lakes. Freshw Biol 15:227-233

Gambin F, Bogé G, Jamet D (1999) Alkaline phosphatase in a littoral Mediterranean marine ecosystem: role of the main plankton size classes. Mar Environ Res 47:441-456

Hansen HP, Grasshoff K (1983) Automated chemical analysis. In: Grasshoff K, Ehrhardt M, Kremling K (eds) Methods of seawater analysis. Weinheim, Verlag Chemie, p 347-379

Hartree EF (1972) Determination of proteins: a modification of the Lowry method that gives a linear photometric response. Anal Biochem 48:422-427

Editorial responsibility: Lars Tranvik, Uppsala, Sweden
Hobbie JE, Daley RJ, Jasper S (1977) Use of Nuclepore filters for counting bacteria by fluorescence microscopy. Appl Environ Microbiol 33:1225-1228

Hoppe HG, Ullrich S (1999) Profiles of ectoenzymes in the Indian Ocean: phenomena of phosphatase activity in the mesopelagic zone. Aquat Microb Ecol 19:139-148

Karner M, Rassoulzadegan F (1995) Extracellular enzyme activity: indications for high short-term variability in a coastal marine ecosystem. Microb Ecol 30:143-156

Koroleff F (1983) Determination of phosphorus. In: Grasshoff K, Ehrhardt M, Kremling K (eds) Methods of seawater analysis. Weinheim, Verlag Chemie, p 125-139

Lorenzen C, Jeffrey J (1980) Determination of chlorophyll in sea water. UNESCO Tech Pap Mar Sci 35:1-20

Misic C, Fabiano M (2005) Enzymatic activity on sandy beaches of the Ligurian Sea (NW Mediterranean). Microb Ecol 49:513-522

Misic C, Povero P, Fabiano M (2002) Ectoenzymatic ratios in relation to particulate organic matter distribution (Ross Sea, Antarctica). Microb Ecol 44:224-234

Mudryk ZJ (2004) Decomposition of organic and solubilisation of inorganic phosphorus compounds by bacteria isolated from a marine sandy beach. Mar Biol 145:1227-1234

Nakamura K, Takaya C (2003) Assay of phosphatase activity and ATP biomass in tideland sediments and classification of the intertidal area using chemical values. Mar Pollut Bull 47:5-9

Palumbo R, Ferguson JE, Rublee PA (1984) Size of suspended bacterial cells and association of heterotrophic activity with size fraction of particles in estuarine and coastal waters. Appl Environ Microbiol 48:157-164

Podgórska B, Mudryk ZJ (2003) Distribution and enzymatic activity of heterotrophic bacteria decomposing selected macromolecular compounds in a Baltic Sea sandy beach. Estuar Coast Shelf Sci 56:539-546

Rath J, Schiller C, Herndl GJ (1993) Ectoenzymatic activity and bacterial dynamics along a trophic gradient in the Caribbean Sea. Mar Ecol Prog Ser 102:89-96

Rusch A, Huettel M, Reimers CE, Taghon GL, Fuller CM (2003) Activity and distribution of bacterial populations in Middle Atlantic Bight shelf sands. FEMS Microbiol Ecol 44:89-100

Ruttenberg KC (1992) Development of a sequential extraction method for different forms of phosphorous in marine sediments. Limnol Oceanogr 37:1460-1482

Sala MM, Karner M, Marrasé C (2001) Measurement of ectoenzyme activities as an indication of inorganic nutrient imbalances in microbial communities. Aquat Microb Ecol 23:301-311

Taylor GT, Way J, Yu Y, Scranton MI (2003) Ectohydrolase activity in surface waters of the Hudson River and western Long Island Sound Estuaries. Mar Ecol Prog Ser 263:1-15

Submitted: November 14, 2006; Accepted: April 10, 2007

Proofs received from author(s): May 22, 2007 